\title{
Node Selection Algorithm for Routing Protocols in VANET
}

\author{
Aruna Sharma ${ }^{1}$ and Simar Preetsingh ${ }^{2}$ \\ ${ }^{1}$ Research Scholar \\ ${ }^{2}$ Assistant Professor DAV University, Jalandhar \\ Dept. of Computer Science and Engineering \\ Iarusharma089@gmail.com, ${ }^{2}$ er.simarpreetsingh@gmail.com
}

\begin{abstract}
VANET stands for vehicular ad-hoc network. Vehicles attached to one another viva a temporary data type an instant system named "VANET".VANET is a technology which is used to getting the information and transmitting the information between the moving vehicles on the road. And the devices are installed on the vehicles like GPS and road transmitter which gives the signal. It incorporates a vehicle to vehicle transmission as well as vehicle to Road side transmission and is important component of ITS (Information transportation system). Node Selection Algorithm purpose to choose next-hop vehicle to help keep in touch with, through utilize "bridging approach" with information forwarding i.e., to select the vehicle from the east (west) to west(east). Quality of services assures is much more challengeable and difficulties MANET than traditional wired network. It is mainly used for hop to hop communication, channel access contention. VANET is to provide safety for passenger and drivers on the road.
\end{abstract}

Keywords: VANET, QOS, NSA, ACO, GV GRID

\section{Introduction}

VANET represents vehicular ad hoc network. It has been subgroup of cellular ad hoc network where communication between two moving nodes on the road. VANET can be used aboard security system for interacting between vehicles as well as roadside infrastructure. It is the kind of network where vehicle as well as roadside unit would be interacting nodes, giving one another with data such as for instant security warning as well as traffic data. It may be more efficient in preventing incidents and traffic congestion than if each vehicle attempts to resolve the issues individually.

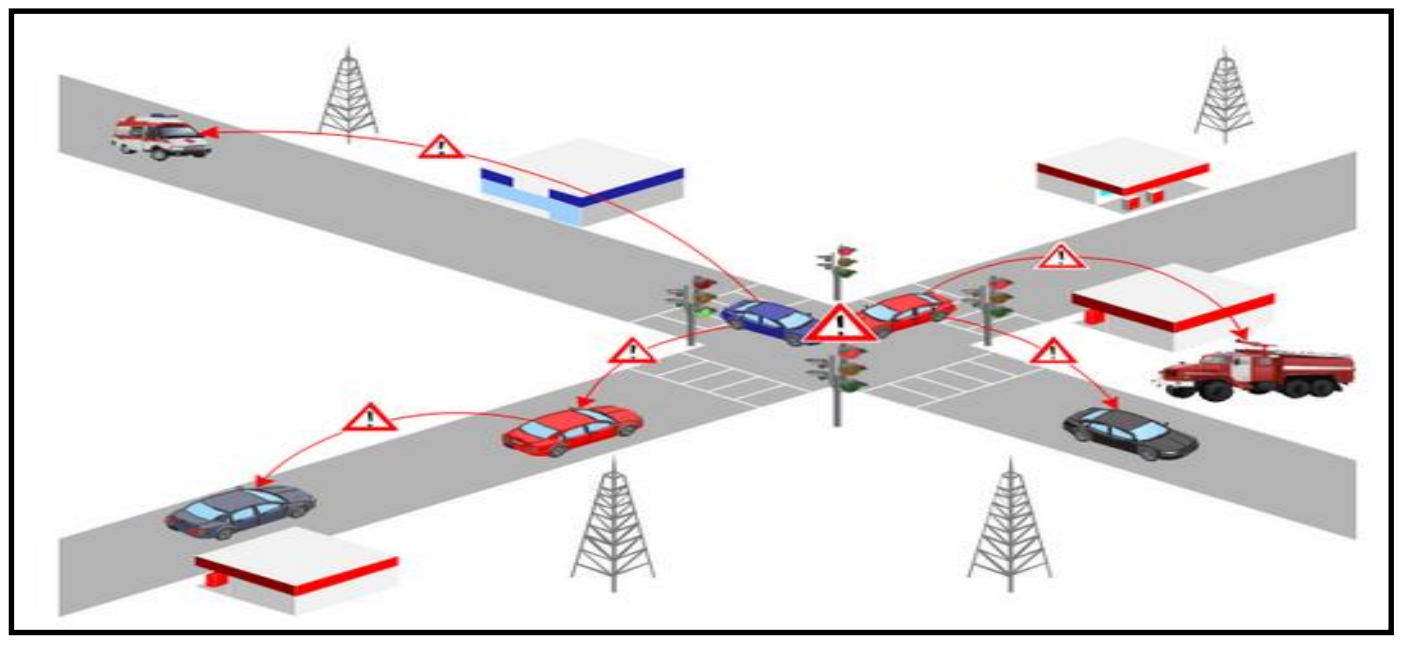

Figure 1. Vehicular Ad Hoc Network (VANET)*

*http://www.ics.uci.edu/ keldefra/figs/vanet.gif 
In which every node can move freely within the network and every node can communicate with other node. This kind of network has the benefit to advise peoples of any occasion happened in the street forward, such as for instant traffic jam, incidents or poor weather. In this manner, the Amount of traffic incidents might reduce and several lives might be saved. Furthermore, an improved choice of non-congested highways will help to minimize pollution. Various exciting companies, such as for instant getting of media companies, could be probable and accessible through infrastructure over the roadside. Giving media service around VANET might need a QOS aware routing protocol that always has to calculate the accessible resources.

Purpose of VANET is to provide comfort for passenger and more efficient travel and also used for life saving for passenger, more efficient travel and also used for life saving for passenger. In VANET the more efficient type of communication are of following:

- Inter-vehicle communication

- Vehicle-to-roadside communication(v-RSU)

- Inter-Roadside Communication

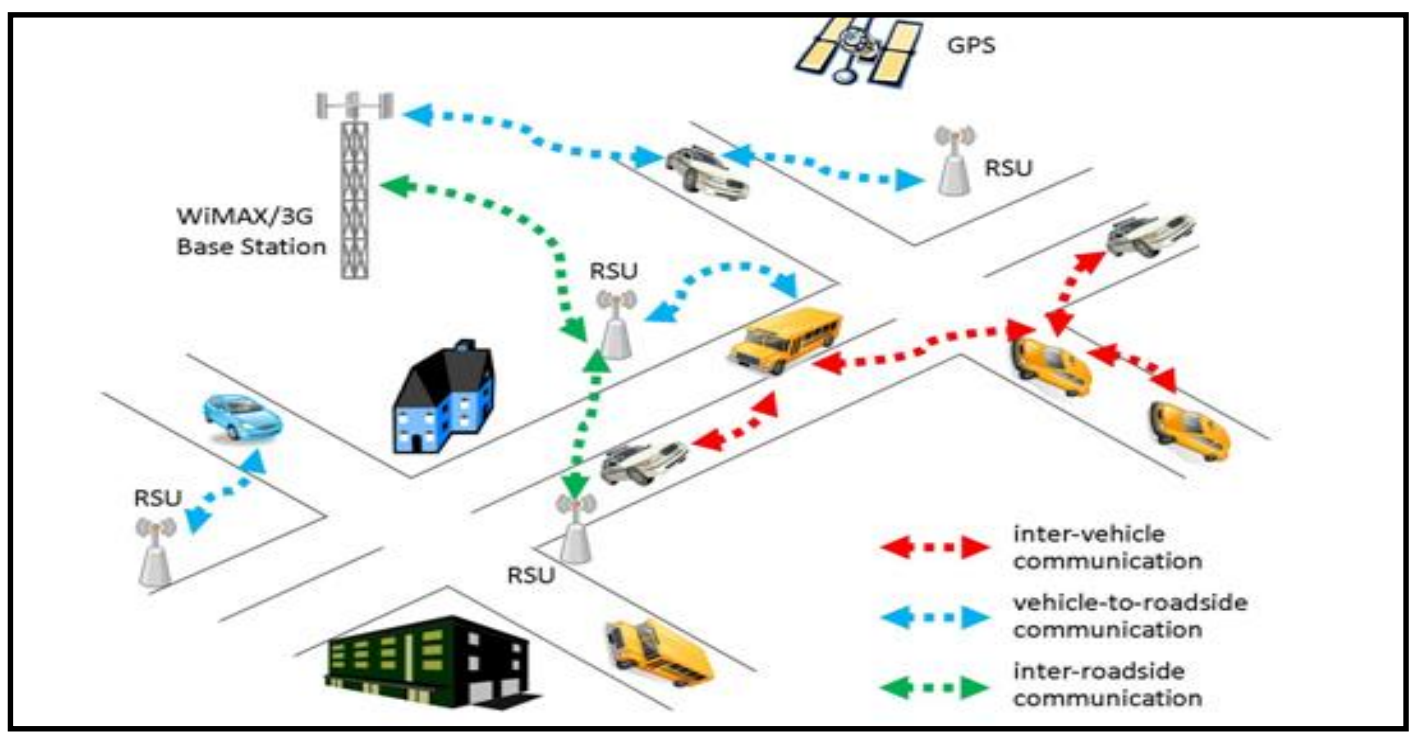

Figure 2. Architecture of VANET

Source: http://adrianlatorre.com/projects/pfc/img/vanet_full.jpg

\section{Applications}

VANET has some different application which makes it unique from MANET as well as challenging for designing VANET characteristic.

\subsection{Safety Application}

Safety application that provide various services like traffic signal violation, curve rate caution, emergency brake lights, pre crash detecting, collision caution, left change guide, street modify caution, and end indicator assist. These applications that increase vehicle or passenger's safety on the roads is called safety application.

\subsection{Non Safety Application}

Non safety application that provide various services like infotainment, internet connectivity, peer to peer communication etc. These applications are called user application. 


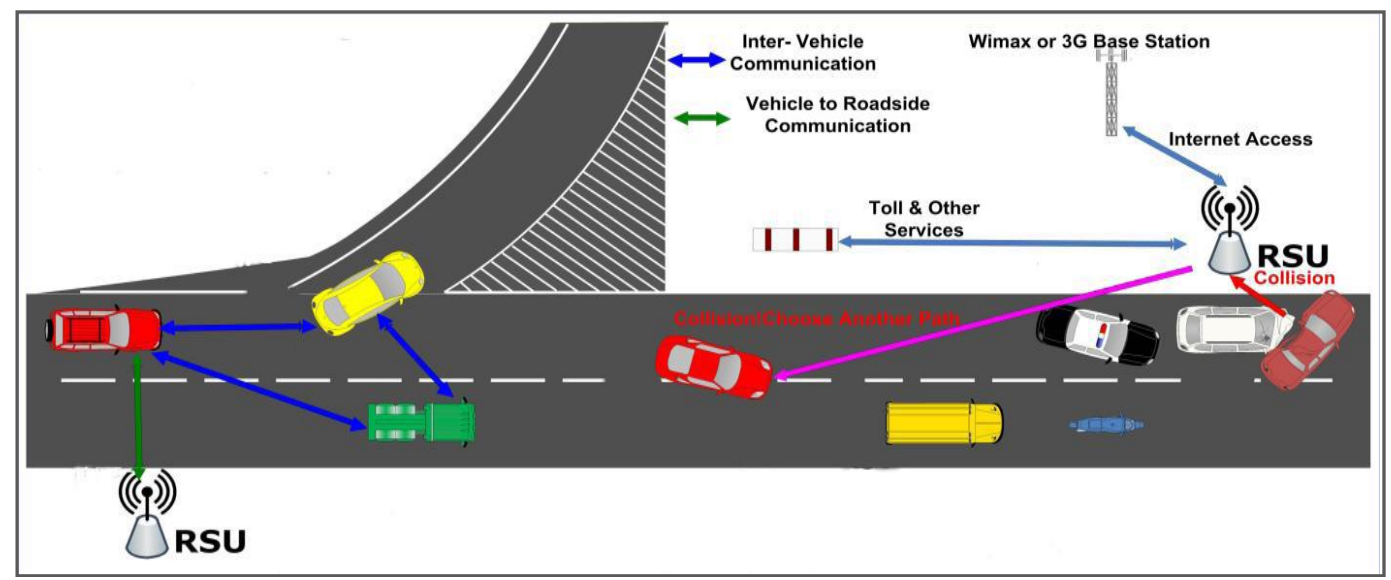

Figure 3. Vehicular Ad Hoc Networks and some Possible Applications

\section{Security Goals}

Aim is to secure the VANET are the same to secure the other network. The secure the VANET is to keep safe the information by an unauthorized node. The main objective is to provide Authentication, confidentiality, integrity and availability.

\subsection{Authentication}

It is the process of determining whether someone or something is, in fact, who or what it is declared to be.

\subsection{Confidentiality}

It is the group of principles or even an offer that restricted accessibility data. It guarantees the privacy of drivers against unauthorized node.

\subsection{Integrity}

It means the information can be modified only by unauthorized node.

\subsection{Availability}

It means that the network works properly and service should be available $24 * 7$.

\section{Routing Protocol}

In VANETs, wireless transmission is a huge important engineering to aid the achievement of several purposes and functions and services. But, as a result of features of VANETs such as for instant large active topology and irregular connection, the present routing algorithms in MANETs aren't designed for many software situations in vehicular ad hoc network. Hence, researchers spare no effort to enhance existing algorithms as well as design new ones, so the transmission stability may be ensured. With respect to the quantity of source and destination included, routing methods may be split into 3 forms: geocast/broadcast, multicast, plus unicast methods.

\subsection{Broadcast}

It is necessity to circulating communications to unknown/unspecified locations, Broadcast protocols that have been requirement in vehicular ad hoc network. The present information transmitted methods on VANETs, like a spatially aware packet routing 
technique, SADV an disturbance aware routing scheme, FROV and a multihop broadcast protocol.

\subsection{Multicast}

Multicast is vital to communications a several cars in a several vehicular situations, such as for immediate intersections, hurdles, more traffic incidence, incidents, and hazardous path road conditions. The multicast standard into 2 major forms. First is topology-based methods, like for instant ODMRP (that generate source-based multicast mesh as well as forwards on the foundation of the class address), MAODV (that generate a tree having group-based multicast), plus GHM (that creates a meshes having groupbased multicast). Second is the methods of location-based, like for instant PBM (that is built on the basis on jobs of most one-hop neighbors as well as jobs of most unique locations), SPBM (that presents hierarchical class membership management), LBM (that works on the multicast area as location data for multicast packets), plus IVG as well as RBM (which establish a multicast selection for security caution messages).

\subsection{Unicast}

Expert examine the unicast connection standards for VANETs in 3 methods: (1) greedy: nodes ahead packets because of their last neighbors towards the location, such as increased greedy traffic-aware routing (GyTAR);(2) opportunistic: nodes utilize the carrytoward method be able to opportunistically offer of the information on location, such as topology-assist geo-opportunistic routing; plus (3) trajectory based: nodes determine probable routes for location and offer the information by vehicles' with more than a single routes.

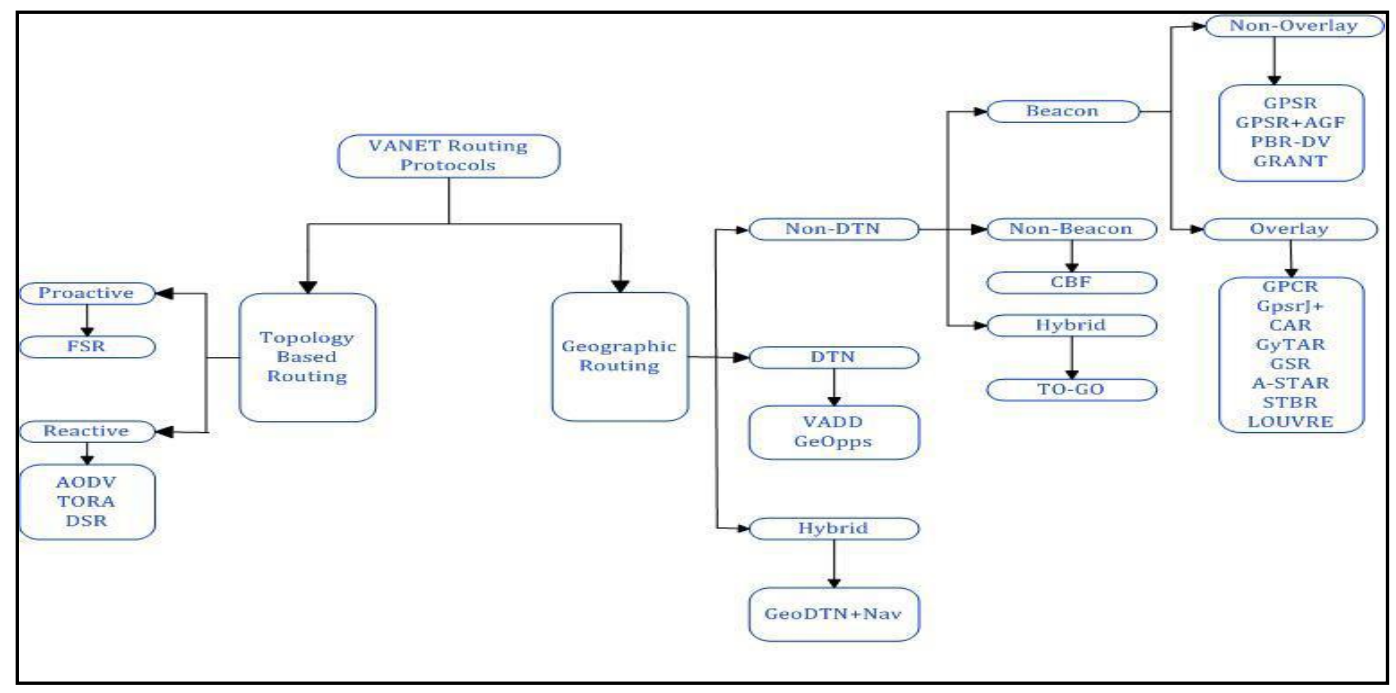

Figure 4. Unicast Routing Protocols in VANET

\section{Related Work}

In [6], QOS Routing protocol named GV Grid designed for VANET.GV Grid need the routing process that build a path from the source (a set node or a platform station) to cars that occur in certain geographical region. To keep up a top quality path is the target of GVGrid, i.e. For the vehicles' movement is an effective path. This type of path may be used for good quality interaction and the information connection between roadsides and vehicles, or between vehicles. The analysis benefits have demonstrate the GV Grid can offer paths with longer entire life, compared by having an current routing process for VANETs. 
In [7], Media interaction around VANET (vehicular ad-hoc networks) may perform an essential position as time goes by intelligent transportation system (ITS). QoS help for vehicular ad hoc network thus become a vital problem. In that report, they examine QoS efficiency for multi-hop VANET utilising typical IEEE 802.11e EDCA MAC plus the planned triple-constraint QoS Routing protocol, DeReHQ is known as Delay-ReliabilityHop. Specifically, they examine the DeReHQ protocol as well as EDCA in roads plus towns.

In [8], VANET is probably the most encouraging part of research. As like different system that system also undergoes by the issues of safety and efficiency. To enhance the QoS with regard to way choice on the system. Here they have planned a fresh biography encouraged routing algorithm as well as usage ant colony optimization method get answers for automobile routing issue (VRP) that is locating an effective automobile path. Now which they take advantage the one of many the generally applied VANET protocol named DYMO, here increasing the DYMO protocol through mixing to ACO. This task has been focus on offering a sensible means to prevent of the issue for obstruction in the event an incident occurs in vehicular system. Ant Colony Optimization is likely to be applied to recognize the secure way from the system at few premature phases.

In [9], Vehicular Ad-Hoc Network (VANET) has attracted large amount of study work because of its applicable in the aspect of highway security, infotainment as well as driving knowledge received at a very really less price. Truly a wireless system, problems in VANET field contains arbitrary packet reduction at data link layer plus at transport layer during certain end to end connection. Failures has been determined by the rate in that the vehicles has been going in the system, Routing protocol applied plus the accessible channel. In that report this has been planned to examining the efficiency of Geographical Routing Protocol (GRP) below arbitrary flexibility having voice as well as traffic.

In [10], Vehicular interaction for intelligent transportation systems can provide security, ease for passengers, and more effective travels. This kind of system has the benefit to advice drivers of any occasion happened in the highway forward, such as for instant traffic jam, incidents or poor weather. In this manner, the amount of traffic incidents might reduce and several lives might be saved. Furthermore, an improved choice of non-congested highways will assist you to minimize pollution. Various other exciting companies, such as for instant accessing of media companies, will be probable and accessible through infrastructure across the roadside. Giving media services around VANETs may require a QoS-aware routing protocol that always have to calculate accessible resources.

In [11], VANET for ITS (Intelligent transportation system) for new year ago to provide QoS, the IEEE 802.11p physical layer, which is represented as VANET protocol, a huge amount of packet losses as a result of collisions. By using Time Division Multiple Access(TDMA) can be enhanced this performance to design a QoS routing protocol which reduced end to end delay while guaranteeing QoS constraint with respect to the propagation delay, throughput utilization. The QoS routing protocol based on LORA-CBF for VANET using TDM scheme LORA-CBF is an extension of protocol. UDP and TCP protocol are used as the real time and best effort to satisfy bandwidth requirement.

In [12], city environment, the vehicle communication is affected by the around obstacles due to the especial condition of wireless channels. However, most of prior works adopt the fixed radio range value of vehicles to transmit packets. They design an optimization forwarding range routing protocol for VANET in urban area. It has an optimized and adjustable forwarding range, which changes with different environments based on the path loss and the city model. And the proposed geo-routing protocol has a novel idea in computing the connectivity of roads and the adjustable strategy in a sparse network.

In [13], QOS-Aware node Selection Algorithm (QASA) for routing protocols to be suitable for a particular class of opportunistic networks, when applied to the Vehicular Ad 
hoc Networks. Our algorithm aims to select the next-hop vehicle to communicate with, by exploiting the "bridging approach" for message forwarding i.e., vehicles on the east (west) select from west (east). The QOS metrics that are being optimized are the throughput in the network, and packets end-to-end delay.

Table 5.1. Related Work

\begin{tabular}{|c|c|c|c|c|}
\hline Title & Author and Year & Abstract & Merits & Demerits \\
\hline $\begin{array}{c}\text { Opportunistic } \\
\text { Networking: } \\
\text { Data Forwarding } \\
\text { in Disconnected } \\
\text { Mobile Ad Hoc } \\
\text { Networks }\end{array}$ & $\begin{array}{c}\text { Luciana Pelusi, } \\
\text { Andrea Passarella, } \\
\text { and Marco Conti } \\
\text { (2006), IEEE } \\
\text { volume 44, Issue } \\
\text { no. } 11 \text {,Page no } \\
\text { 134-141. }\end{array}$ & $\begin{array}{l}\text { The best situation } \\
\text { report linked to } \\
\text { opportunistic } \\
\text { networking are } \\
\text { surveyed and a } \\
\text { taxonomy is } \\
\text { organized about } \\
\text { the primary } \\
\text { routing as well as } \\
\text { forwarding } \\
\text { methods in this } \\
\text { tricky } \\
\text { Environment. }\end{array}$ & $\begin{array}{c}\text { Routes are } \\
\text { designed } \\
\text { dynamically, } \\
\text { while } \\
\text { communications } \\
\text { are en path } \\
\text { between the } \\
\text { source plus the } \\
\text { target, as well as } \\
\text { any probable node } \\
\text { may } \\
\text { opportunistically } \\
\text { utilized as next } \\
\text { hop, offered it } \\
\text { will probable to } \\
\text { carry information } \\
\text { nearer to the last } \\
\text { location. }\end{array}$ & $\begin{array}{c}\text { Networks like } \\
\text { city-bus network, } \\
\text { mesh network are } \\
\text { missing. }\end{array}$ \\
\hline $\begin{array}{l}\text { Analytical Model } \\
\text { for Connectivity } \\
\text { in Vehicular Ad } \\
\text { Hoc Networks }\end{array}$ & $\begin{array}{l}\text { Saleh Yousefi, } \\
\text { Eitan Altman, } \\
\text { Rachid El-Azouzi, } \\
\text { and Mahmood } \\
\text { Fathy(2006), } \\
\text { IEEETransactions } \\
\text { on 57, no. } 6 \text {,page } \\
\text { no 3341-3356. }\end{array}$ & $\begin{array}{l}\text { It is presented for } \\
\text { understanding } \\
\text { connection in } \\
\text { vehicular ad hoc } \\
\text { network. This } \\
\text { connection is in } \\
\text { the ad hoc } \\
\text { network formed } \\
\text { among } \\
\text { automobiles } \\
\text { which travel } \\
\text { ahead usual road } \\
\text { is investigated. }\end{array}$ & $\begin{array}{l}\text { Description of } \\
\text { affects of } \\
\text { numerous network } \\
\text { parameters, like } \\
\text { road congestion } \\
\text { parameters } \\
\text { (such as speed } \\
\text { distribution as } \\
\text { well as traffic } \\
\text { flow) plus the } \\
\text { broadcasting } \\
\text { selection of } \\
\text { automobiles, } \\
\text { based on the } \\
\text { connection. }\end{array}$ & $\begin{array}{l}\text { Lack of channel } \\
\text { randomness and } \\
\text { realistic traffic } \\
\text { patterns in } \\
\text { models. }\end{array}$ \\
\hline
\end{tabular}




\begin{tabular}{|c|c|c|c|c|}
\hline $\begin{array}{l}\text { Access Point } \\
\text { Placement in } \\
\text { Vehicular } \\
\text { Networking }\end{array}$ & $\begin{array}{l}\text { Ashish Agrawal } \\
\text { and Thomas D.C. } \\
\text { Little } \\
2008 .\end{array}$ & $\begin{array}{l}\text { The issue of } \\
\text { accessibility level } \\
\text { positioning is } \\
\text { recognized as in a } \\
\text { hybrid vehicular } \\
\text { networking } \\
\text { Environment } \\
\text { composed of } \\
\text { multihop } \\
\text { transmission } \\
\text { around moving } \\
\text { automobiles } \\
\text { supported by } \\
\text { access points. }\end{array}$ & $\begin{array}{l}\text { Below delay } \\
\text { resistant } \\
\text { networking } \\
\text { presumption, } \\
\text { minimal delay and } \\
\text { maximum } \\
\text { propagation } \\
\text { rates may be } \\
\text { performed for } \\
\text { minimal vehicular } \\
\text { traffic densities. }\end{array}$ & $\begin{array}{c}\text { Average } \\
\text { propagation rate } \\
\text { can be improved } \\
\text { further. }\end{array}$ \\
\hline $\begin{array}{l}\text { Hybrid vehicular } \\
\text { communications } \\
\text { based on V2V- } \\
\text { V2I protocol } \\
\text { switching }\end{array}$ & $\begin{array}{c}\text { Anna Maria } \\
\text { Vegni and } \\
\text { Thomas D.C. } \\
\text { Little, } 2011\end{array}$ & $\begin{array}{c}\text { It is shown } \\
\text { Where connection } \\
\text { is given by } \\
\text { equally current } \\
\text { network } \\
\text { infrastructure via } \\
\text { a vehicle-to- } \\
\text { infrastructure } \\
\text { protocol plus } \\
\text { conventional } \\
\text { vehicle-to-vehicle } \\
\text { networking. }\end{array}$ & $\begin{array}{l}\text { Characterizes the } \\
\text { most and least } \\
\text { bounds of } \\
\text { message } \\
\text { propagation as } \\
\text { well as } \\
\text { comparison of } \\
\text { performance } \\
\text { with conventional } \\
\text { message } \\
\text { propagation on } \\
\text { the basis of } \\
\text { opportunistic } \\
\text { networking. }\end{array}$ & $\begin{array}{l}\text { Lack of real time } \\
\text { validations and } \\
\text { simulations. }\end{array}$ \\
\hline $\begin{array}{l}\text { Distributed } \\
\text { Quality-of- } \\
\text { Service } \\
\text { Routing in Ad } \\
\text { Hoc Networks }\end{array}$ & $\begin{array}{c}\text { Shigang Chen and } \\
\text { Klara Nahrstedt, } \\
1999 .\end{array}$ & $\begin{array}{l}\text { A distributed } \\
\text { QoS routing } \\
\text { system which } \\
\text { chooses a network } \\
\text { route having } \\
\text { enough } \\
\text { methods to meet a } \\
\text { particular delay } \\
\text { (or bandwidth) } \\
\text { necessity } \\
\text { in a dynamic } \\
\text { multihop mobile } \\
\text { environment. }\end{array}$ & $\begin{array}{c}\text { More call } \\
\text { admission } \\
\text { Ratio and less- } \\
\text { cost routes has } \\
\text { been } \\
\text { accomplished } \\
\text { along simple } \\
\text { routing overhead. }\end{array}$ & $\begin{array}{l}\text { Lack of secure } \\
\text { communication } \\
\text { environment. }\end{array}$ \\
\hline $\begin{array}{c}\text { Design and } \\
\text { Evaluation of Hi- } \\
\text { CAST and its } \\
\text { Variants for } \\
\text { Safety Message } \\
\text { Dissemination in } \\
\text { VANET }\end{array}$ & $\begin{array}{c}\text { Ihn-Han Bael and } \\
\text { Stephan Olariu, } \\
2013 .\end{array}$ & $\begin{array}{c}\text { A hybrid } \\
\text { intelligent } \\
\text { broadcast } \\
\text { algorithm Hi- } \\
\text { CAST and their } \\
\text { numerous } \\
\text { variations have } \\
\text { now been } \\
\text { prlanned for alert } \\
\text { message } \\
\text { dissemination in } \\
\text { VANET. }\end{array}$ & $\begin{array}{l}\text { Hi-CAST is more } \\
\text { advanced than } \\
\text { Different } \\
\text { algorithms in } \\
\text { collision and } \\
\text { achievement. }\end{array}$ & $\begin{array}{l}\text { Hi-CAST is } \\
\text { longer than } \\
\text { Simple and p- } \\
\text { Persistence } \\
\text { algorithms in time } \\
\text { because it uses the } \\
\text { delay broadcast } \\
\text { protocol. }\end{array}$ \\
\hline
\end{tabular}




\begin{tabular}{|c|c|c|c|c|}
\hline $\begin{array}{l}\text { A probabilistic } \\
\text { routing by using } \\
\text { multi-hop } \\
\text { retransmission } \\
\text { forecast with } \\
\text { packet collision- } \\
\text { aware constraints } \\
\text { in vehicular } \\
\text { networks }\end{array}$ & $\begin{array}{c}\text { Ahmad Mostafa, } \\
\text { Anna Maria } \\
\text { Vegni, Dharma P. } \\
\text { Agrawal, 2013. }\end{array}$ & $\begin{array}{l}\text { A novel reliable } \\
\text { and low-collision } \\
\text { packet-forwarding } \\
\text { scheme called } \\
\text { Collision-Aware } \\
\text { REliable } \\
\text { FORwarding } \\
\text { (CAREFOR) has } \\
\text { been proposed for } \\
\text { vehicular ad hoc } \\
\text { networks, is } \\
\text { formulated by } \\
\text { probabilistic } \\
\text { rebroadcasting. }\end{array}$ & $\begin{array}{l}\text { Performance gain } \\
\text { in terms of the } \\
\text { throughput, and } \\
\text { the percentage of } \\
\text { successful } \\
\text { transmissions. }\end{array}$ & $\begin{array}{c}\text { Lack of } \\
\text { validations in real } \\
\text { urban traffic } \\
\text { scenarios. }\end{array}$ \\
\hline $\begin{array}{c}\text { CAREFOR: } \\
\text { Collision- } A \text { ware } \\
\text { REliable } \\
\text { FORwarding } \\
\text { Technique for } \\
\text { Vehicular Ad hoc } \\
\text { Networks }\end{array}$ & $\begin{array}{c}\text { Anna Maria } \\
\text { Vegni, Ahmad } \\
\text { Mostafa and } \\
\text { Dharma P. } \\
\text { Agrawal, 2013. }\end{array}$ & $\begin{array}{l}\text { A probability- } \\
\text { based multi-hop } \\
\text { broadcast } \\
\text { protocol, named } \\
\text { Collision-Aware } \\
\text { REliable } \\
\text { FORwarding } \\
\text { (CAREFOR) is } \\
\text { proposed for } \\
\text { applications in } \\
\text { vehicular } \\
\text { networks. }\end{array}$ & $\begin{array}{l}\text { Lesser collision } \\
\text { probability, more } \\
\text { throughputs, and } \\
\text { eventually, a more } \\
\text { amount of } \\
\text { effective } \\
\text { transmissions. }\end{array}$ & $\begin{array}{c}\text { Lack of efficiency } \\
\text { in real time } \\
\text { scenarios. }\end{array}$ \\
\hline $\begin{array}{l}\text { An Evaluation of } \\
\text { Routing Protocols } \\
\text { with Probabilistic } \\
\text { Relay in VANETs }\end{array}$ & $\begin{array}{c}\text { Radityo Anggoro, } \\
\text { Ryoji Nakamura, } \\
\text { Teruaki Kitasuka, } \\
\text { Tsuyoshi Itokawa, } \\
\text { Masayoshi } \\
\text { Aritsugi, 2011. }\end{array}$ & $\begin{array}{l}\text { It is defined the } \\
\text { way in which } \\
\text { probabilistic relay } \\
\text { can impact the } \\
\text { routing efficiency } \\
\text { for OLSR as well } \\
\text { as AODV below } \\
\text { VANETs } \\
\text { environments. }\end{array}$ & $\begin{array}{l}\text { Improvement in } \\
\text { vehicle mobility } \\
\text { as well as road } \\
\text { segment length. }\end{array}$ & $\begin{array}{l}\text { Lack of reliability } \\
\text { of the network. }\end{array}$ \\
\hline $\begin{array}{l}\text { An optimization } \\
\text { forwarding range } \\
\text { routing protocol } \\
\text { Protocol for } \\
\text { VANET in City } \\
\text { Environments }\end{array}$ & $\begin{array}{l}\text { LI Xiao qing1, L } \\
\text { I Hui1, YANG } \\
\text { Kai2 a n d L I U } \\
\text { Q i a o,Jan,2014 }\end{array}$ & $\begin{array}{l}\text { An optimization } \\
\text { range forwarding } \\
\text { protocol for } \\
\text { vanets in urban } \\
\text { areas which have } \\
\text { optimized as well } \\
\text { as adjustable } \\
\text { forwarding range } \\
\text { that improvement } \\
\text { with various } \\
\text { environments. }\end{array}$ & $\begin{array}{c}\text { It has an } \\
\text { enhanced results } \\
\text { in sparse network } \\
\text { as well as city } \\
\text { environment }\end{array}$ & $\begin{array}{l}\text { Lack of security } \\
\text { and efficiency }\end{array}$ \\
\hline
\end{tabular}




\begin{tabular}{|c|c|c|c|c|}
\hline $\begin{array}{l}\text { CARAVAN: } \\
\text { Context-AwaRe } \\
\text { Architecture for } \\
\text { VANET }\end{array}$ & $\begin{array}{c}\text { Sawomir } \\
\text { Kukliński1 and } \\
\text { Grzegorz } \\
\text { Wolny,Jan } 2011\end{array}$ & $\begin{array}{l}\text { Vanet concepts } \\
\text { are integrated into } \\
\text { popular platform } \\
\text { and utilize them } \\
\text { on the dependence } \\
\text { of the service } \\
\text { needs, } \\
\text { connectivity } \\
\text { attributes and } \\
\text { node mobility } \\
\text { features. }\end{array}$ & $\begin{array}{l}\text { The work is } \\
\text { performed in } \\
\text { layers the } \\
\text { Mobility Layer, } \\
\text { the Connectivity } \\
\text { Layer as well as } \\
\text { the Application } \\
\text { Layer. }\end{array}$ & $\begin{array}{l}\text { Lack of real time } \\
\text { scenarios. }\end{array}$ \\
\hline $\begin{array}{l}\text { A QoS Approach } \\
\text { for Cluster-Based } \\
\text { Routing in } \\
\text { VANETS Using } \\
\text { TDMA Scheme }\end{array}$ & $\begin{array}{l}\text { bubakar Aminu } \\
\text { Mu'azu, Low } \\
\text { Tang Jung, } \\
\text { Ibrahim A. } \\
\text { Lawal1, Peer } \\
\text { Azmat Shah,2013 }\end{array}$ & $\begin{array}{c}\text { Proposed a } \\
\text { QoS routing } \\
\text { protocol effective } \\
\text { at locating as } \\
\text { well as organizing } \\
\text { a route } \\
\text { by clustering } \\
\text { method applying } \\
\text { TDMA }\end{array}$ & $\begin{array}{c}\text { Enhanced } \\
\text { throughput } \\
\text { provided UDP as } \\
\text { well as TCP } \\
\text { traffic classes. }\end{array}$ & $\begin{array}{l}\text { Lack of multi-hop } \\
\text { communication }\end{array}$ \\
\hline $\begin{array}{l}\text { Performance } \\
\text { Evaluation of } \\
\text { Geographical } \\
\text { Routing } \\
\text { Protocol under } \\
\text { Different Traffic } \\
\text { Scenario }\end{array}$ & $\begin{array}{l}\text { A. Tamizhselvi } \\
\text { and Dr. R.S.D. } \\
\text { Wahida Banu, } \\
\text { March } 2012\end{array}$ & $\begin{array}{c}\text { Proposed a } \\
\text { Geographical } \\
\text { Routing Protocol } \\
\text { (GRP) below } \\
\text { random mobility } \\
\text { having voice as } \\
\text { well as } \\
\text { Traffic. }\end{array}$ & $\begin{array}{l}\text { End to End delay } \\
\text { has been } \\
\text { extensible lesser } \\
\text { for video } \\
\text { traffic in } \\
\text { comparison to } \\
\text { voice traffic, } \\
\text { performs properly } \\
\text { for video data is } \\
\text { relatively terms of } \\
\text { end to end delay } \\
\text { plus throughput. }\end{array}$ & $\begin{array}{l}\text { Loss of packets } \\
\text { i.e. packets are } \\
\text { dropped while } \\
\text { communicating. }\end{array}$ \\
\hline $\begin{array}{l}\text { GVGrid: A QoS } \\
\text { Routing Protocol } \\
\text { for } \\
\text { Vehicular Ad Hoc } \\
\text { Networks }\end{array}$ & $\begin{array}{c}\text { Weihua Sun, } \\
\text { Hirozumi } \\
\text { Yamaguchi, Koji } \\
\text { Yukimasa, Shinji } \\
\text { Kusumoto,2006 }\end{array}$ & $\begin{array}{l}\text { GVGrid for multi- } \\
\text { hop mobile ad hoc } \\
\text { networks built } \\
\text { by automobiles } \\
\text { that builts a path } \\
\text { on demand from a } \\
\text { sender (a fixed } \\
\text { node or a } \\
\text { base station) to } \\
\text { automobiles that } \\
\text { reside in or drive } \\
\text { through a given } \\
\text { Geographical } \\
\text { region. }\end{array}$ & $\begin{array}{l}\text { GVGrid can offer } \\
\text { paths with longer } \\
\text { life time, } \\
\text { compared by } \\
\text { having an existing } \\
\text { routing protocol } \\
\text { for VANETs }\end{array}$ & $\begin{array}{l}\text { Maximum road } \\
\text { maps having } \\
\text { different vehicle } \\
\text { densities as well } \\
\text { as Mobility to } \\
\text { address the } \\
\text { efficiency of this } \\
\text { protocol. }\end{array}$ \\
\hline
\end{tabular}




\begin{tabular}{|c|c|c|c|c|}
\hline $\begin{array}{l}\text { On-demand QoS } \\
\text { and Stability } \\
\text { Based Multicast } \\
\text { Routing in Mobile } \\
\text { Ad Hoc Networks }\end{array}$ & $\begin{array}{l}\text { P. I. Basarkod and } \\
\text { Sunilkumar S. } \\
\text { Manvi,March } \\
2014\end{array}$ & $\begin{array}{l}\text { It is the stability } \\
\text { on the basis of } \\
\text { multicast routing } \\
\text { (OQSMR) system } \\
\text { is formulated, that } \\
\text { will be an } \\
\text { expansion of } \\
\text { ad hoc on-demand } \\
\text { multicast routing } \\
\text { protocol } \\
\text { (ODMRP) to } \\
\text { offer QoS means } \\
\text { for real time } \\
\text { purposes. }\end{array}$ & $\begin{array}{l}\text { Lowering of } \\
\text { packet overhead, } \\
\text { development in } \\
\text { Packet Delivery } \\
\text { Ratio (PDR), as } \\
\text { well as reduction } \\
\text { in end-to-end } \\
\text { delays when } \\
\text { comparsion is } \\
\text { done with } \\
\text { ODMRP, as well } \\
\text { as improved } \\
\text { ODMRP (E- } \\
\text { ODMRP) }\end{array}$ & $\begin{array}{l}\text { Lack of delay } \\
\text { distribution } \\
\text { among nodes in } \\
\text { the path. }\end{array}$ \\
\hline $\begin{array}{l}\text { An Ant based } \\
\text { Algorithm for } \\
\text { Vehicular Ad-hoc } \\
\text { Networks }\end{array}$ & $\begin{array}{l}\text { Poonam Narwal, } \\
\text { Naveen Goel, Dr } \\
\text { Arun K Khosla, } \\
\text { July } 2012\end{array}$ & $\begin{array}{l}\text { Ant colony } \\
\text { optimization } \\
\text { technique is } \\
\text { employed to } \\
\text { search answers to } \\
\text { the vehicle } \\
\text { routing problem } \\
\text { (VRP) i. e. to } \\
\text { search an } \\
\text { reliable vehicle } \\
\text { path. }\end{array}$ & $\begin{array}{l}\text { Provides an } \\
\text { intelligent answer } \\
\text { to ignore the issue } \\
\text { of traffic in case } \\
\text { an } \\
\text { Incident happens } \\
\text { in vehicular } \\
\text { network. ACO } \\
\text { can be used to } \\
\text { describe the safe } \\
\text { route from the } \\
\text { network. }\end{array}$ & $\begin{array}{l}\text { Some other } \\
\text { optimization } \\
\text { algorithms can } \\
\text { also be used. }\end{array}$ \\
\hline
\end{tabular}

\section{Conclusion}

Our aim is to select the next hop vehicle to communicate for message forwarding, they have improve the QOS in terms of path over the network. To find solution to the vehicle routing protocol (VRP) i.e., to find an efficient vehicle Route. For that the make use one of the commonly used VANET protocol called DYMO, here they improving the DYMO protocol by combining it with ACO. The work is about to provide an intelligent solution to avoid the problem of congestion in case an accident happen in vehicular network. ACO will be used to identify the safe path from the network. Being a wireless network, Issues in VANET domain include random packet loss in transport layer and in data link layer for a given end to end connection.

\section{Future Scope}

VANET is used on board safety system for communicating between vehicles and roadside infrastructure. In which every node can move freely within the network and every node can communicate with other node. This way, the number of traffic accidents may decrease and many lives could be saved. Node selection algorithm is to select the next-node vehicle to communicate for message forwarding; we have to improve the QOS in terms of path on the network. So that less number of packets lost at which the nodes are moving within the network, the better routing protocol used.

\section{References}

[1] L. Pelusi, A. Passerella and A. Conti, "Opportunistic Networking: Data Forwarding in Disconnected Mobile Ad Hoc Networks", IEEE Communications Mag., vol. 44, (2011).

[2] S. Yousefi, E. Altman, R. El-Azouzi and M. Fathy, "Analytical Model for Connectivity in Vehicular Ad Hoc Networks”, IEEE Trans. of Vehicular Technology, vol. 57, (2006). 
[3] A. Agarwal and T. Little, "Access Point Placement in Vehicular Networking”, Proc. of 1st Intl. Conf. on Wireless Access in Vehicular Environments, Troy, MI, (2008).

[4] A. M. Vegni and T. D. C. Little, "Hybrid vehicular communications based on v2v-v2i protocol switching", International Journal of Vehicle Information and Communication Systems, (2011), pp. 213231.

[5] A. M. Vegni and T. D. C. Little, "A message propagation model for hybrid vehicular communication protocols", Communication Systems Networks and Digital Signal Processing (CSNDSP), 2010 7th International Symposium on, IEEE, (2010), pp. 382-386.

[6] S. Weihua and Y. Hirozumi, "GV Grid: A QoS Routing Protocol for Vehicular Ad Hoc Networks", IEEE, (2006) June, pp. 130-139.

[7] Z. Niu, W. Yao and Q. Ni, "Study on QOS Support in 802.11 e-based multi-hop Vehicular wireless Adhoc Network", IEEE International conference on networking, sensing and control, London, UK, (2007) April, pp. 15-17.

[8] N. Poonam, G. Naveen and Dr K. Arun, "An Ant based Algorithm for Vehicular Ad-hoc Networks", International Journal of Scientific \& Engineering Research, vol. 3, no. 7, (2012) July.

[9] Tamizhselvi and Dr. R. S. D. Wahida Banu, "Performance Evaluation of Geographical Routing Protocol under Different Traffic Scenario", International Journal of Computer Science and Telecommunications, vol. 3, no. 3, (2012) March.

[10] B. Carolina Tripp, M. Mezher Ahmad and A. Igartua M’onica, "Available Bandwidth-aware Routing in Urban Vehicular Ad-hoc Networks", IEEE, (2012).

[11] M. Abubakar Aminu, J. Low Tang, A. Lawal Ibrahim and A. Shah Peer, "A QoS Approach for ClusterBased Routing in VANET Using TDMA Scheme”, IEEE, (2013), pp. 212-217.

[12] X. Li, H. Li, K. Y. and Q. Liu, "An Optimization Forwarding Range Routing Protocol for VANET in City Environments", Chinese Journal of Electronics, vol. 23, no. 1, (2014) January.

[13] M. Ahmad, V. Anna Maria and B. Asitha, "QoS-aware Node Selection Algorithm for Routing Protocols in VANET", Fourth International Conference on Selected Topics in Mobile \& Wireless Networking, vol. 40, (2014), pp. 66-73.

[14] A. M. Vegni and T. D. C. Little, "Hybrid vehicular communications based on v2v-v2i protocol switching", International Journal of Vehicle Information and Communication Systems, (2011), pp. 213231.

[15] A. M. Vegni and T. D. C. Little, "A message propagation model for hybrid vehicular communication protocols", in: Communication Systems Networks and Digital Signal Processing (CSNDSP), 2010 7th International Symposium on, IEEE, (2010), pp. 382-386.

[16] S. Chen and K. Nahrstedt, "Distributed Quality-of-Service Routing in Ad-hoc Networks", IEEE Journal on Selected Areas in Communications, vol. 17, no. 8, (1999), pp. 1488-1505.

[17] I.-H. Bae and S. Olariu, "Design and evaluation of hi-cast and its variants for safety message dissemination in vanet", Control, Automation and Systems (ICCAS), 2013 13th Intl. Conf., (2013), pp. 800-806

[18] J. Kim, Q. Zhang and D. P. Agrawal, "Probabilistic broadcasting based on coverage area and neighbor confirmation in mobile ad hoc networks", Proc. IEEE Global Telecomm. Conf. (GLOBECOM), (2004).

[19] A. Mostafa, A. M. Vegni and D. P. Agrawal, "A Probabilistic Routing by using Multi-hop Retransmission Forecast with Packet Collision-Aware Constraints in Vehicular Networks", Ad Hoc Networks (Elsevier), (2014), pp. 14 118-129.

[20] A. M. Vegni, A. Mostafa and D. P. Agrawal, "Carefor: Collision-aware reliable forwarding technique for vehicular ad hoc networks", Computing, Networking and Communications (ICNC), Intl. Conf. on, IEEE, (2013), pp. 773-777.

[21] R. Anggoro, R. Nakamura, T. Kitasuka, T. Itokawa and M. Aritsugi, "An evaluation of routing protocols with probabilistic relay in VANETs”, TENCON 2011 - 2011 IEEE Region 10 Conf., (2011), pp. 187191.

[22] H. Hartenstein and K. Laberteaux, "VANET: Vehicular Applications and Inter-networking Technologies", Wiley \& sons, Ltd., (2010). 
International Journal of Advanced Science and Technology Vol.96 (2016) 